\title{
Possibilities and limitations of individual-tree growth models - A review on model evaluations
}

\section{Möglichkeiten und Grenzen von Waldwachstumsmodellen - Eine Übersicht über Modellevaluierungen}

\author{
Sonja Vospernik
}

\begin{abstract}
${ }^{1}$ Institute of Forest Growth and Yield, Department of Forest and Soil Sciences, University of Natural Resources and Life Sciences Vienna (BOKU), Peter-Jordan-Straße 82, 1190 Vienna, Austria

Corresponding author: sonja.vospernik@boku.ac.at
\end{abstract}

Received: 28 April 2017, received in revised form: 18 August 2017, accepted: 21 August 2017

\begin{abstract}
Summary
Individual-tree growth models are the new standard for modeling growth and yield. Their main purpose is to simulate future forest management scenarios but they can also be used to predict wood quality, rockfall protection or habitat quality. Individual tree growth models may consist of different models but core models are diameter increment, height increment, crown ratio (often used as a predictor for increment) and mortality. The model differentiation is based on how these four models include tree age (size), competition and site. Four common growth simulators in Central Europe are BWIN, Moses, Prognaus and Silva. These four models are commonly deployed to simulate 30 years of growth, but a prospective application is the simulation of a whole rotation period (80-150 years). It is therefore crucial to understand the possibilities and limitations of these models by evaluating them. This review paper summarizes the statistical and emergent properties' evaluation results for these models. Statistical evaluations focus on individual models of a simulator, whereas the evaluation of emergent properties evaluates the entire simulator, by testing if the models conform to known principles of stand growth. Further, the meaning of these evaluation results for the development and improvement of individual-tree growth models is discussed.
\end{abstract}

Keywords: emergent properties, statistical evaluation, growth simulator, model performance

\section{Zusammenfassung}

Einzelbaumwachstumsmodelle sind der heutige Standard in der Waldwachstumsmodellierung. Ihr wichtigster Zweck ist die Simulation von Waldbewirtschaftungsszenarien, aber sie können auch zur Prognose von Holzqualität, Steinschlagschutz oder Habitatqualität verwendet werden. Einzelbaumwachstumsmodelle bestehen aus unterschiedlichen Teilmodellen. Sie beinhalten jedoch meist ein Durchmesserzuwachsmodell, ein Höhenzuwachsmodell, eine Kronenmodell (Kronenparameter werden oft als unabhängige Variable in den Zuwachsmodellen verwendet) und ein Mortalitätsmodell. Die Unterscheidung zwischen verschiedenen Modellansätzen basiert darauf, wie das Baumalter, die Konkurrenz und der Standort in diesen vier Kernmodellen abgebildet werden. Vier bekannte Einzelbaumwachstumsmodelle in Mitteleuropa sind BWIN, Moses, Prognaus und Silva. Diese vier Modelle werden derzeit für 30-jährige Wachstumsprognosen eingesetzt, eine künftige Anwendung ist die Simulation einer ganzen Umtriebszeit (80-150 Jahre). Für die praktische Anwendung von Wachstumsmodellen ist es essentiell, ihre Möglichkeiten und Einschränkungen durch Modellevaluierung zu verstehen. Diese Übersichtsarbeit fasst Ergebnisse von statistischen Evaluierungen und Evaluierungen mittels „Emergent properties“ von Waldwachstumsmodellen zusammen. Bei der statistischen Evaluierung werden die einzelnen Modelle des Simulators untersucht. Bei der Evaluierung mittels „Emergent properties“ wird der gesamte Wachstumssimulator getestet, indem die Übereinstimmung von Simulationsergebnissen mit bekannten Waldwachstumsgesetzmäßigkeiten beurteilt wird. Darüber hinaus wird die Bedeutung dieser Evaluierungsergebnisse für die Weiterentwicklung von Einzelbaumwachstumsmodellen diskutiert.

Schlagworte: Emergent properties, Statistische Evaluierung, Waldwachstumssimulator, Leistungsvergleich von Modellen 


\section{Individual tree growth models}

Individual tree growth models have been developed to provide flexible predictions of forest growth. Thus, individual tree growth models became "the new standard for modeling growth and yield in many regions of the world" (Weiskittel et al., 2011). A major purpose of individual tree growth models is to simulate forest management scenarios. Because they provide detailed information on manifold output variables, individual tree growth models give answers to questions from many scientific fields. For example, individual tree growth models have been applied to predict future wood quality (e.g., Maguire et al., 1991; Sterba et al., 2006), to derive decision support with respect to rockfall protection (Brauner et al., 2005) and to assess the forest's habitat suitability (Debeljak et al., 2001; Marzluff et al., 2002; Vospernik and Reimoser, 2008). Due to their high relevance in academics as well as in decision support of forest practice, individual tree growth models have to be carefully evaluated and permanently updated.

Individual tree growth models usually consist of a set of core models for major target variables, including diameter increment, height increment, crown ratio and mortality. Because management decisions often require precise and accurate predictions, existing individual tree growth models have been evaluated in many studies (Sterba et al., 2001; Pretzsch, 2002; Kindermann and Hasenauer, 2007; Schmidt and Hansen, 2007).

Model evaluation provides end-users with information on the accuracy of the model. It gives insight into errors and deficiencies, and helps in improving the models. Model evaluation examines whether the model provides realistic predictions throughout the likely range of application, the equations adequately represent the processes involved, the equations have been combined correctly in the model and the models are biologically realistic (Hann, 1980; Vanclay and Skovsgaard, 1997). It is not possible to examine all these aspects in a single evaluation study.

Evaluations mainly focus on prognoses for mid-term periods with a duration of approximately 30 years, which corresponds to the maximum recommended time horizon of forest growth projections with individual-tree growth models (Nagel and Schmidt, 2006; Pretzsch et al., 2006; Klopf, 2014).These evaluations are mainly statistical evaluations. To further extend the applicability of individual tree growth models to longer periods (e.g., 150 years, approximately one rotation period in Central Europe), long term growth behavior has to be examined (Vospernik et al., 2015). Also, an extension of individual tree growth models to conceptual terms of natural stand dynamics is desirable (Huber, 2011).

Whereas growth is modeled for individual trees, predictions are also required for stand-level attributes. Thus, stand-level predictions are usually obtained via 'up-scaling', which simply sums up all the predictions of individual trees together representing a complete forest stand (Weiskittel et al., 2011). In so doing, it must be guaranteed that up-scaled individual prognoses altogether reflect a plausible behavior that can be expected as the realistic representation of a forest stand development in total. For this purpose, it is important to examine whether the stand-level predictions obtained from up-scaled individual predictions follow some predefined 'emergent properties' (Monserud et al., 2004; Weiskittel et al., 2011; Vospernik et al., 2015). Such emergent properties are formed by the realistic development of basal area, stem number and total timber volume per area unit over time. The examination of emergent properties of individual tree growth models does not evaluate individual models, but enables insight into the structure and behavior of the whole growth model. For a specific individual tree growth model, examples for the evaluation of emergent properties are: Pretzsch (2002), Monserud et al. (2004) and Huber (2010; 2011). Each of these studies focuses on the evaluation of a single individual tree growth model. A comprehensive comparison of different Central European growth models can be found in Vospernik et al. $(2010 ; 2015)$. This approach allows to evaluate performances and to assess inherent strengths and weaknesses of the different growth models. This evaluation also revealed that some stand growth principles required to test the emergent properties of individual-tree growth models are not yet fully understood. Examples are competition-density and self-thinning rule (Vospernik and Sterba, 2015), growth in young stands (Vospernik et al., 2010), mixed (Sterba et al., 2002, Pretzsch et al., 2017) and uneven-aged stands (Schmid et al., 2006) and growth patterns for minor species, for which evaluations are still lacking.

\section{Structure of individual tree growth models}

The core of individual tree growth models is the functions to predict the diameter increment and height increment. 
Because crown ratio is usually a predictor for diameter and height increment, functions to estimate or update crown ratio are usually also included (static and dynamic crown ratio models) (e.g., Pretzsch, 2001; Weiskittel et al., 2011). Prognoses of stand level parameters are then obtained by summing up growth projections for individual trees. In addition to growth, forest stands are mainly affected by two additional processes, namely mortality and regeneration. Whereas useful models already exist for mortality, regeneration is not well understood so far (e.g., Pretzsch, 2001; Weiskittel et al., 2011). Major explanatory variables of the three core models for growth, mortality and regeneration can be summarized into tree size characteristics, competition measures and site variables. Individual tree growth models can be further classified according to the type of implemented diameter/height increment model. In several models, a potential growth maximum is fixed for the given site conditions and is subsequently reduced dependent on other covariates from size measures and competition. This is in contrast to other model approaches, where a potential growth maximum is not a priori fixed. Competition is sometimes modeled using spatially explicit information on tree positions, whereas other models use coarse overall density measures together with the measures of social position within the diameter at breast height (dbh)-distribution (e.g., basal area of larger trees). And finally, some of the existing growth models are based on site index curves, whereas others use multivariate regressions for increment predictions dependent on various specific site characteristics. Models with a growth potential usually use the growth of open-grown trees as a potential for diameter increment and site index curves of dominant trees as a potential for height increment. This maximum growth is then reduced by a modifier function. Model approaches without fixed growth potential directly provide diameter and height increment predictions. If a specific growth potential is fixed, future prognoses cannot exceed a range of plausible values because growth predictions are restricted by an upper boundary. However, if the growth potential is incorrectly defined, this introduces an additional source of error (e.g., Pretzsch, 2001; Weiskittel et al., 2011). Individual tree growth models can be spatial (distance-dependent) or non-spatial (distance-independent). The first ones require information on the spatial distribution of trees to calculate inter-tree distances, the latter can be easily calculated from a tree list (Ledermann, 2010). A way to combine the advantages of both spatial and non-spatial indices might be semi-distance independent indices (Stage and Ledermann, 2008). That is, if distance-independent indices are calculated from a small plot, they can no longer be considered distance independent, because the trees on such a small sample plot are likely to compete for resources. Furthermore, growth models can be classified into models that use site index and models that use site factors. The strength of using site index is its proven efficacy in predicting volume growth and yield, and the strength of relationship between tree height and age in even-aged forests (Weiskittel et al., 2011). Despite its wide utility, site index has some limitations as a productivity measure. The most important include that it is difficult to apply in mixed or uneven-aged stands and that it can change over time for a given stand (Weiskittel et al., 2011). Methods for the determination of site index in mixed stands have been presented by Zingg (1994) and Sterba (1996). The calculation of site index in uneven-aged stands is however still an unsolved problem. Examples of individual tree growth models representing these different approaches according to the outlined classification in Central Europe are:

BWIN (Nagel, 1999; 2009) uses a potential for height increment but not for diameter increment. It uses a static crown model. Initially, it was developed as a non-spatial model, but today a spatial variant exists. Site quality is represented by site index.

Moses (Hasenauer, 1994; Kindermann and Hasenauer, 2005) uses a potential diameter and height increment model, a dynamic crown model and spatial measures of competition. Again, site quality is represented by site index.

Prognaus (Monserud and Sterba, 1996; 1999; Nachtmann, 2006) directly models diameter and height increment and uses a static crown model. The competition model is nonspatial and site quality is represented by site factors.

Silva (Pretzsch, 1992; Kahn and Pretzsch, 1998; Pretzsch et al., 2002) uses a potential for diameter and height increment, and a spatial measure of competition. The crown model is static and the site is represented by species-specific unimodal dose-response functions based on climate and site factors. These values are then aggregated into ecological variables.

This evaluation study will mainly focus on these four models because they have been thoroughly evaluated (e.g., Sterba et al. 2001; Pretzsch 2002; Kindermann and Hasenauer 2007; Schmidt and Hansen 2007) and are widely used for growth and yield predictions. 


\section{Statistical evaluation}

A common way to statistically examine models is to compare the observations and predictions of individual equations. Several measures have been proposed for statistical evaluations: among them are bias, precision, root mean square error and efficiency. Bias is the expected deviation of prediction function from the truth and is calculated as the mean difference between model predictions and observations (Fahrmeir et al., 2007). Precision of a function is quantified by its prediction variance (Fahrmeir et al., 2007). Overall model performance is assessed by means of the root-mean-square error defined as prediction variance plus bias-squared (Fahrmeir et al., 2007). Model efficiency was proposed by Loague and Green (1991). The efficiency tests if the model predictions are better than the mean of observed values. An efficiency of 1 indicates a perfect model, 0 indicates that the mean is as good a predictor as the model, a negative efficiency means that the model is inefficient as its explanatory power is less than the mean. A comprehensive statistical evaluation of all core models of the individual tree growth simulator Prognaus was presented by Vospernik and Eckmüllner (2012). In this study, the bias ranged between $-4.4 \%$ and $+33 \%$ for $\mathrm{dbh}$, height, crown ratio and volume. Bias of the models for diameter increment, basal area increment, height increment or volume increment was larger and ranged between $-27.9 \%$ and $+57.9 \%$. Precision and root mean square error varied between $10 \%$ and $100 \%$. Static variables, such as $\mathrm{dbh}$, height, crown ratio and volume were more precisely predicted than dynamic variables in terms of increment measures. Evaluation results obtained for different individual tree growth models are within the range of other studies (e.g., Pretzsch and Dursky, 2001; Sterba et al., 2001; Pretzsch, 2002; Froese and Robinson, 2007; Schmidt and Hansen, 2007; Mette et al., 2009).

Commonly, observations and predictions can also be plotted against each other and regression lines can be fit to the data. This would allow for assessing whether the shape of the relationship between response and covariates is correctly modeled. In case a model is well-specified, data points are homogenously aligned around a line having zero intercept and slope one. Hypothesis tests for parameter estimates, that is, whether intercept and slope significantly deviates from zero and slope from one, are based on t-tests. In case large data exist, quantiles from the standard Gaussian distribution can be used instead. The disadvantage of statistical tests is that as the sample size becomes larger, even small and practically negligible deviations become significant, whereas with a small sample size, important differences might not be detected. A test that circumvents this problem is a test of equivalence (Berger and Hsu, 1996; Robinson and Froese, 2004). An examination of residuals and t-test and test of equivalence were for example presented by Vospernik and Eckmüllner (2012) for Prognaus. The examination of residual plots sometimes shows that small increments were overestimated and large increments were underestimated (Vospernik and Eckmüllner, 2012). Most other trends of the residuals were only weak, including spatial trends (Vospernik and Eckmüllner, 2012).

Probably one of the most important findings from statistical evaluations is that model calibration does not improve model performance. Theoretically, calibration should account for regional factors not accounted for by the model. For example, Stage (1973) suggested calibrating the model with the median difference between actual and predicted increment from the first inventory period. However, calibration often fails due to the high temporal variability of the increments, because it may introduce a temporal bias (Vospernik and Eckmüllner, 2012). This hypothesis is also supported by the fact, that in contrast to expectations from error propagation, predictions were more precise for longer evaluation periods (Sterba and Monserud, 1997; Pretzsch, 2002; Albrecht, 2007; Vospernik and Eckmüllner, 2012). Statistical evaluation results are regionally very different. This may partly be explained by varying growth patterns. For example, a large number of yield tables with regionally different height growth patterns exist. However, in individual tree growth models there is often only a single height growth pattern implemented.

\section{Biological principles}

A different type of model evaluation is the comparison of model output with well-known principles of forest growth. This type of evaluation examines the model structure as a whole and tests if stand growth behavior emerges as the sum of tree-level growth processes. Important principles of stand growth are the self-thinning line, competition-density-rule, density-growth relationships or height:diameter ratios. The self-thinning line (Reineke, 1933) (eq. 1) represents the maximum density that can be attained for a certain species across sites and therefore represents overall maximum density of a tree species in a certain region. Self-thinning is therefore a marginal case of competition- 
density relationship (Vospernik and Sterba, 2015). The competition-density rule relies on a strong relationship between stem number and quadratic mean diameter for a given dominant height (eq. 2).

$$
\begin{aligned}
& \ln (N)=c_{0}+c_{1} \cdot \ln \left(d_{g}\right) \\
& d_{g}=\frac{1}{a_{0} \cdot h_{d o m}^{a_{1}} \cdot N+b_{0} \cdot h_{d o m}^{b_{1}}}
\end{aligned}
$$

$\begin{array}{ll}d_{g} & \text { quadratic mean diameter } \\ N & \text { stem number per hectare } \\ b_{d o m} & \text { dominant height } \\ a_{0}, a_{1}, b_{0^{\prime}}, b_{1} & \text { coefficients of the competition density rule } \\ c_{0^{0}}, c_{1} & \text { coefficients of the self-thinning line }\end{array}$

Robust estimation techniques allow parameterizing both rules from national forest inventory data, even for minor species (e.g., Vospernik and Sterba, 2015). An important question for the evaluation of individual tree growth models is: "Can a tree-specific mortality model elicit expected forest stand density dynamics represented by the self-thinning rule or competition-density rule without imposing stand-level constraints?" Monserud et al. (2004) examined this question for the growth model Prognaus on 27 plots for Norway spruce and Scots pine. Results for Norway spruce confirmed that the maximum size-density relationship was reasonably predicted by Prognaus. Scots pine also displayed stable stand dynamics, but greatly exceeded Reineke's maximum stand density index determined from the literature. The test with the competition-density rule revealed that the estimated maximum stand density index according to Sterba's theory (1987) was too high for both species, but relative ranking was correct.

Another way to evaluate the emergent properties of individual-tree growth models with respect to density is to test, if they conform to the Langsaeter hypothesis. The Langsaeter hypothesis summarizes the entire size-density relationship: Over a certain range of densities, stand volume growth is almost constant or at optimum level (Assmann, 1970), because the remaining trees can compensate or overcompensate for losses in standing volume. Below a certain threshold, however, growth decreases almost linearly. The effect of density on stand and tree growth may vary with tree species, age and site (Assmann, 1970). Because of their crown architecture, some species can react quickly to occupy free areas (e.g., European beech - Ken- nel, 1972; Bryndum 1987), some are intermediate (e.g., Norway spruce - Schober, 1979; Mäkinen and Isomäki, 2004) whereas others react only slowly (e.g., Scots pine - Kramer and Röös, 1989). Generally, young stands react more quickly to the additional growing space provided through wider initial spacing or thinning, and the capacity to respond to release declines with age (Assmann, 1970). Some controversy exists on the effect of site: The study of Pretzsch (2005) suggests that Norway spruce generally reacts with increased growth rates on poor sites and with lower growth rates under favorable site conditions. European beech behaves in quite the opposite manner.

An evaluation of the Langsaeter hypothesis for the four individual-tree growth models BWIN, Moses, Prognaus and Silva and three different tree species (Scots pine, Norway spruce, European beech) was presented by Vospernik et al. (2015). The response of density to thinning was simulated by decreasing basal area in $5 \%$ or $10 \%$ steps using thinning from below. From the simulation output also, the critical basal area, where $95 \%$ of the potential maximum for a site can be achieved (Assmann, 1970), was calculated. The results showed that in most cases, the predictions were below maximum basal area obtained from the Austrian National Forest Inventory or the yield tables of Assmann and Franz (1963), but on poor sites, the maximum basal areas of yield tables of Assmann and Franz (1963) were exceeded. In most cases, predictions by the four simulators conformed to the Langsaeter hypothesis, and species specific differences were correctly reflected. Critical basal area increased with age, except for Norway spruce simulated with BWIN. Differences in the predicted critical basal areas were however large. For Norway spruce and European beech, the predicted critical basal area was considerably higher for Prognaus and Silva than for BWIN and Moses (Vospernik et al., 2015).

The effect of density on tree growth cannot only be examined at the stand level, but also at the individual tree level. One way to examine the effect of density on an individual tree level is height:diameter ratios. In an attempt to maintain canopy position in the stand, height growth is not or little reduced, whereas diameter increment and crown development decreases. As a result, trees under severe competition have higher height:diameter ratios than dominant or open-grown trees.

The paper "Do individual tree growth models correctly represent height:diameter ratios for Norway spruce and Scots pine" by Vospernik et al. (2010) evaluates whether the height:diameter ratio is realistically and precisely pre- 
dicted by BWIN, Moses, Prognaus and Silva. Individual growth prognoses were simulated under fixed predetermined conditions. Open-grown tree behavior was predicted by planting 1 tree per hectare with a dbh of $10 \mathrm{~cm}$ on a good, average and poor site, defined by using the best, average and worst site index at the age of 100 years according to the yield tables "Fichte Hochgebirge" and "Kiefer Litschau". Corresponding heights and age were taken from open-grown tree relations (Stampfer, 1995) and the respective yield tables. Spruce was simulated till it reached a $\mathrm{dbh}$ of $80 \mathrm{~cm}$; pine was simulated till it reached a dbh of $60 \mathrm{~cm}$. The predicted open-grown tree diameters ranged from $44 \mathrm{~cm}$ to $245 \mathrm{~cm}$ on good sites and between $24 \mathrm{~cm}$ to $42 \mathrm{~cm}$ on poor sites. Diameters obtained corresponded surprisingly well to the published open-grown tree diameters (Lässig, 1991; Stampfer, 1995; Hasenauer, 1997). Differences in open-grown tree diameters between good and poor sites can be as large as $78 \mathrm{~cm}$ and as small as $26 \mathrm{~cm}$, indicating that the effect of site is described very differently by the four simulators. Crown ratios for open-grown trees were always 1 for Moses by constraint. Prognaus predicted a crown ratio $>0.96$ for spruce and a crown ratio $>0.67$ for pine. Crown ratios predicted by BWIN and Silva were highly variable during the simulation period, ranging from 0.28 to 0.99 .

For the resulting height:diameter ratios there were four cases: (1) increment and allometry correct, (2) height or diameter increment wrong, allometry distorted, (3) height and diameter increment wrong, allometry correct, (4) height and diameter increment wrong, allometry distorted. To examine the height:diameter ratios in dense stands, it was examined if maximum values were exceeded in any specific dbh class. Maximum values were always below the overall maximum observed by the Austrian National Forest Inventory. All four models predicted higher height:diameter ratios for mean trees than for dominant trees and higher height:diameter ratios for denser stands.

Another known principle of stand growth is the age of increment culmination. This specific age strongly depends on the tree species. For a given tree species, the earlier the culmination point is achieved, the better the site conditions are; although the opposite may also occur (Wenk and Gerold, 1991; Sterba and Eckmüllner, 2010). With respect to thinning, it has been shown that the increment on thinned plots culminates earlier (Assmann, 1970). Evaluations of the age of increment culmination showed, that Norway spruce mean annual increment culminated at 79, 100, 101 and 127 years for Moses, BWIN, Prognaus and
Silva on good sites and 25-48 years later on poor sites. Culmination age ranged between 60 and 90 years for Scots pine and between 136-159 years for European beech (except for Moses, where it culminated at 29 years). In most cases, mean annual increment culminated at an earlier age, if heavy thinning was applied (Vospernik et al., 2015).

Summarizing, evaluations of emergent properties showed that most relevant principles of plant growth are correctly reflected by the examined growth models. For example, the individual-tree growth models react to density management in a logical way. They are capable of simulating open-grown trees as well as very dense stands. However, the evaluations detected several shortcomings of the models. Some of the shortcomings are only found for a specific individual-tree growth model (BWIN, Moses, Prognaus, Silva) and need to be addressed for the respective model. Other errors are persistent across models. For example, all simulators exceeded maximum density for a particular species or site, indicating a lack of site-specific mortality models or self-thinning boundary lines. Also, simulations of heavy thinning variants differ considerably more between the simulators. This might show a lack of heavy thinning variants in the data.

With respect to different model types, model evaluation did not find any particular modeling approach superior to others and choice between approaches may simply be a matter of preference or convenience or data available (Wykoff, 1990). For example, in many evaluations, no differences between spatial and non-spatial models were found (Biging and Dobbertin, 1995; Windhager, 1999; Vospernik et al., 2010; 2015). However, there seems to be a difference between the models using site factor and models using site index. Models using site factors mainly represent large-scale variation in site, whereas site index allows for a better adaption to local site variation.

\section{Conclusions and Outlook}

Individual tree growth models were extensively evaluated with respect to predictions of traditional growth and yield parameters. Statistical evaluation studies find relatively large prognosis uncertainty for individual tree growth models. These uncertainties are due to measurement errors, natural variability, limited data and model bias. To date, these uncertainties are not addressed in simulations with individual tree growth models. It would be important 
to correctly address the sources of those uncertainties because otherwise, the model output may mislead the users of growth models to wrong management decisions.

Individual tree growth models could be improved, when modern and statistically sound calibration techniques are applied based on mixed-model approaches together with empirical Bayesian estimators (Lappi and Bailey, 1988; Lappi, 1991, 1997; Lappi and Malinen, 1994; Mehtätalo, 2004, 2005; Nothdurft et al., 2006). Other possible remedies are a careful re-examination of sub-models, fitting constrained sub-models, the analysis of the model structure, the development of an adequate calibration procedure and the development of regionally different sub-models. Moreover, for an adequate fitting of individual tree growth models, additional datasets might be needed. For example, for mortality or heavy thinning variants those are usually not sufficiently represented in the datasets used for individual tree growth models. Finally, there is also a lack of understanding of some important complex processes in forests. Examples are growth patterns for minor species, the complex processes in mixed or uneven-aged stands, correct prediction for the dynamics of young stands, growth processes in sparsely stocked stands or on poor sites.

\section{References}

Albrecht, A. (2007): Evaluierung des Waldwachstumssimulators Silva 2.2 anhand langfristiger ertragskundlicher Versuchsflächen in Baden-Württemberg. In: Nagel, J. (Ed.): Deutscher Verband forstlicher Forschungsanstalten, Sektion Ertragskunde, Jahrestagung 2007, AlsfeldEudorf, 154-163.

Assmann, E. (1970): The principles of forest yield study. Pergamon Press, Oxford, UK.

Assmann, E. and F. Franz (1963): Vorläufige Fichtenertragstafeln für Bayern. Institut für Ertragskunde der forstlichen Forschungsanstalt München, München.

Berger, R.L. and J.C. Hsu (1996): Bioequivalence trials, intersection tests and equivalence confidence sets. Statistical Science 11, 283-319.

Biging, G.S. and M. Dobbertin (1995): Evaluation of competition indices in individual tree growth models. Forest Science 41, 360-377.

Brauner, M., Weinmeister, W., Agner, P., Vospernik, S. and B. Hoesle (2005): Forest management decision support for evaluating forest protection effects against rockfall. Forest Ecology and Management 207, 75-85.
Bryndum, H. (1987): Buchen-Durchforstungsversuch in Dänemark. Allgemeine Forst- und Jagdzeitung 158, 115-122.

Debeljak, M., Dzeroski, S., Jerina, K., Kobler, A. and M. Adamic (2001): Habitat suitability modelling for red deer (Cervus elaphus L.) in South-central Slovenia with classification trees. Ecological Modelling 138, 321-330.

Fahrmeir, L., Künstler, R., Pigeot, I. and G. Tutz (2007): Statistik. Der Weg zur Datenanalyse. Springer, Berlin, Heidelberg, New York.

Froese, R.E. and A.P. Robinson (2007): A validation and evaluation of the Prognosis individual-tree basal area increment model. Canadian Journal of Forest Research 37, 1438-1449.

Hann, D.W. (1980): Development and evaluation of an even- and uneven-aged ponderosa pine/Arizona fescue stand simulator. Research paper INT-267. USDA Forest Service, Ogden, UT.

Hasenauer, H. (1994): Ein Einzelbaumwachstumssimulator für ungleichaltrige Fichten- Kiefern und $\mathrm{Bu}$ chen-Fichtenmischbestände. Österreichische Gesellschaft für Waldökosystemforschung und experimentelle Baumforschung, Wien.

Hasenauer, H. (1997): Dimensional relationships of opengrown trees in Austria. Forest Ecology and Management 96, 197-206.

Huber, M.O. (2010): The steady state species composition simulated by BWINPro. Austrian Journal of Forest Science 127, 71-96.

Huber, M.O. (2011): The evidence of stand development stages in simulations by an individual-tree growth simulator. Canadian Journal of Forest Research 41, 124-138. Kahn, M. and H. Pretzsch (1998): Konzeption und Konstruktion von Wuchs- und Prognosemodellen für Mischbestände in Bayern. Konzeption und Konstruktion des Wochsmodells Silva 2.2. Lehrstuhl für Waldwachstumskunde, München.

Kennel, R. (1972): Die Buchendurchforstungsversuche in Bayern von 1870 bis 1970 . Forstlicher Forschungsbericht München 7, München.

Kindermann, G. and H. Hasenauer (2005): Zusammenstellung der Oberhöhenfunktionen für die wichtigsten Baumarten in Österreich. Austrian Journal of Forest Science 122, 163-184.

Kindermann, G. and H. Hasenauer (2007): Vergleich von Grundflächenzuwachsprognose von Ertragstafel und dem Baummodell Moses. Austrian Journal of Forest Science 124, 63-81. 
Klopf, M. (2014): Moses: A single tree growth simulator for forest management planning. PhD thesis, Universität für Bodenkultur, Wien.

Kramer, H. and M. Röös (1989): Durchforstungsversuch in einem weitständig begründeten Kiefernbestand. Forst und Holz 44, 139-144.

Lappi, J. (1991): Calibration of height and volume equations with random parameters. Forest Science 37, 781801.

Lappi, J. (1997): A longitudinal analysis of height/ diameter curves. Forest Science 43, 555-570.

Lappi, J. and R.L. Bailey (1988): A height prediction model with random stand and tree parameters: an alternative to traditional site index methods. Forest Science 34, 907-927.

Lappi, J. and J. Malinen (1994): Random-parameter height/age models when stand parameters and stand age are correlated. Forest Science 40, 715-731.

Lässig, R. (1991): Zum Wachstum von Fichtensolitären (Picea abies (L.) Karst.) in Südwestdeutschland. PhD thesis, Albert-Ludwigs-Universität Freiburg im Breisgau.

Ledermann, T. (2010): Evaluating the performance of semi-distance-independent competition indices in predicting the basal area growth of individual trees. Canadian Journal of Forest Research 40, 796-805.

Loague, K. and R.E. Green (1991): Statistical and graphical methods for evaluating solute transport models: Overview and application. Journal of Contaminant Hydrology 7, 51-73.

Maguire, D.A., Kershaw, J.A. and D.W. Hann (1991): Predicting the effects of silvicultural regime on branch size and crown wood core in Douglas-Fir. Forest Science 37, 1409-1428.

Marzluff, J.M., Millspaugh, J.J., Ceder, K.R., Oliver, C.D., Withey, J., McCarter, J.B., Mason, C.L. and J. Comnick (2002): Modeling changes in wildlife habitat and timber revenues in response to forest management. Forest Science 48, 191-202.

Mehtätalo, L. (2004): A longitudinal height-diameter model for Norway spruce in Finland. Canadian Journal of Forest Research 34, 131-140.

Mehtätalo, L. (2005): Height-Diameter models for Scots pine and birch in Finland. Silva Fennica 39, 55-66.

Mette, T., Albrecht, A., Ammer, C., Biber, P., Kohnle, U. and H. Pretzsch (2009): Evaluation of the forest growth simulator SILVA on dominant trees in mature mixed Silver fir-Norway spruce stands in South-West Germany. Ecological Modelling 220, 1670-1680.
Monserud, R.A., Ledermann, T. and H. Sterba (2004): Are self-thinning constraints needed in a tree-specific mortality model? Forest Science 50, 848-858.

Monserud, R.A. and H. Sterba (1996): A basal area increment model for individual trees growing in even- and uneven-aged forest stands in Austria. Forest Ecology and Management 80, 57-80.

Monserud, R.A. and H. Sterba (1999): Modeling individual tree mortality for Austrian forest species. Forest Ecology and Management 113, 109-123.

Mäkinen, H. and A. Isomäki (2004): Thinning intensity and growth of Norway spruce stands in Finland. Forestry 77, 349-364.

Nachtmann, G. (2006): Height increment models for individual trees in Austria depending on site and competition. Austrian Journal of Forest Science 123, 199-222.

Nagel, J. (1999): Konzeptionelle Überlegungen zum schrittweisen Aufbau eines waldwachstumskundlichen Simulationssystems für Norddeutschland. Paul Parey Verlag, Schriftenreihe der Forstlichen Fakultät der Universität Göttingen, Band 128, pp. 122.

Nagel, J. (2009): Waldwachstumssimulation mit dem Java Software Paket TreeGross. Nordwestdeutsche Forstliche Versuchsanstalt, Göttingen.

Nagel, J. and M. Schmidt (2006): The silvicultural decision support system BWINPro. In: Hasenauer, $\mathrm{H}$. (Ed.): Sustainable forest management. Growth models for Europe. Springer Verlag, Berlin, 59-63.

Nothdurft, A., Kublin, E. and J. Lappi (2006): A nonlinear hierarchical mixed model to describe tree height growth. European Journal of Forest Research 125, 281289.

Pretzsch, H. (1992): Konzeption und Konstruktion von Wuchsmodellen für Rein- und Mischbestände. Forstlicher Forschungsbericht 115, Forstwissenschaftliche Fakultät der Universität München und Bayerische Forstliche Versuchs- und Forschungsanstalt.

Pretzsch, H. (2001): Modellierung des Waldwachstums. Paul Parey, Berlin, Wien.

Pretzsch, H. (2002): Application and evaluation of the growth simulator Silva 2.2 for forest stands, forest estates and large regions. Forstwissenschaftliches Zentralblatt 121, 28-51.

Pretzsch, H. (2005): Stand density and growth of Norway spruce (Picea abies (L.) Karst.) and European beech (Fagus sylvatica L.): evidence from long-term experimental plots. European Journal of Forest Research 124, 193-205. 
Pretzsch, H., Biber, P. and J. Dursky (2002): The single tree-based stand simulator SILVA - construction, application and evaluation. Forest Ecology and Management 162, 3-21.

Pretzsch, H., Biber, P., Dursky, J. and R. Sodtke (2006): The individual-tree based stand simulator SILVA. In: Hasenauer, H. (Ed.): Sustainable forest management. Growth models for Europe. Springer Verlag, Berlin, 78-84.

Pretzsch, H. and J. Dursky (2001): Evaluierung von Waldwachstumssimulatoren auf Baum- und Bestandesebene. Allgemeine Forst- und Jagdzeitung 172, 146-150.

Pretzsch, H., Rötzer, T. and D.I. Forrester (2017): Modelling mixed-species forest stands. In: Pretzsch, H., Forrester D.I. and J. Bauhaus (Eds.): Mixed-species forests. Springer Verlag, Berlin, 383-431.

Reineke, L.H. (1933): Perfecting a stand-density index for even-aged forests. Journal of Agricultural Research 46, 627-638.

Robinson, A.P. and R.E. Froese (2004): Model validation using equivalence tests. Ecological Modelling 176, 349-358.

Schmid, S., Zingg, A., Biber, P. and H. Bugmann (2006): Evaluation of the forest growth model SILVA along an elevational gradient in Switzerland. European Journal of Forest Research 125, 43-55.

Schmidt, M. and J. Hansen (2007): Valdierung der Durchmesserzuwachsprognosen des Wachstumssimulators BWINPro 7.0 für Fichte und Buche für den Bereich der alten Bundesländer. In: Nagel, J. (Ed.): Sektion Ertragskunde Jahrestagung 2007, Alsfeld-Eudorf, 164-179.

Schober, R. (1979): Massen-, Sorten- und Wertertrag der Fichte bei verschiedener Durchforstung. Allgemeine Forst- und Jagdzeitung 150, 129-152.

Stage, A.R. (1973): Prognosis model for stand development. USDA Forest Service. INT-137, Intermount Forest and Range Experiment Station, Ogden, UT, USA.

Stage, A.R. and T. Ledermann (2008): Effects of competitor spacing in a new class of individual-tree indices of competition: semi-distance-independent indices computed for Bitterlich versus fixed-area plots. Canadian Journal of Forest Research 38, 890-898.

Stampfer, E. (1995): Solitärdimensionen österreichischer Baumarten. Diploma thesis, Universität für Bodenkultur, Wien.

Sterba, H. (1987): Estimating potential density from thinning experiments and inventory data. Forest Science 33, 1022-1034.
Sterba, H. (1996): Oberhöhendefinition im gleichaltrigen Mischwald. Schweizerische Zeitschrift für das Forstwesen 147, 109-120.

Sterba, H., Blab, A. and K. Katzensteiner (2002): Adapting an individual tree growth model for Norway spruce (Picea abies L. KARST) in pure and mixed species stands. Forest Ecology and Management 159, 101-110. Sterba, H. and O. Eckmüllner (2010): Bonität und Kulmination des Höhenzuwachses. Allgemeine Forst- und Jagdzeitung 181, 14-21.

Sterba, H., Korol, N. and G. Rössler (2001): Ein Ansatz zur Evaluierung eines Einzelbaumwachstumssimulators für Fichtenreinbestände. Forstwissenschaftliches Zentralblatt 120, 406-421.

Sterba, H. and R.A. Monserud (1997): Applicability of the forest stand growth simulator PROGNAUS for the Austrian part of the Bohemian Massif. Ecological Modelling 98, 23-34.

Sterba, H., Vospernik, S., Söderbergh, I. and T. Ledermann (2006): Harvesting rules and modules for predicting commercial timber assortments. In: Hasenauer, $\mathrm{H}$. (Ed.): Sustainable Forest Management - Growth models for Europe, Springer, Berlin Heidelberg, 111-130.

Vanclay, J.K. and J.P. Skovsgaard (1997): Evaluating forest growth models. Ecological Modelling 98, 1-12.

Vospernik, S. and O. Eckmüllner (2012): Evaluation of the individual tree growth model Prognaus. Austrian Journal of Forest Science 129, 22-55.

Vospernik, S., Monserud, R.A. and H. Sterba (2010): Do individual-tree growth models correctly represent height:diameter ratios of Norway spruce and Scots pine? Forest Ecology and Management 260, 1735-1753.

Vospernik, S., Monserud, R.A. and H. Sterba (2015): Comparing individual-tree growth models using principles of stand growth for Norway spruce, Scots pine, and European beech. Canadian Journal of Forest Research 45, 1006-1018.

Vospernik, S. and S. Reimoser (2008): Modelling changes in roe deer habitat in response to forest management. Forest Ecology and Management 255, 530-545.

Vospernik, S. and H. Sterba (2015): Do competition-density rule and self-thinning rule agree? Annals of Forest Science 72, 379-390.

Weiskittel, A.R., Hann, D.W., Kershaw, J.A. and J.K. Vanclay (2011): Forest Growth and Yield Modeling. WileyBlackwell, Oxford.

Wenk, G. and Gerold, D. (1991): Methodik der Konstruktion von Ertragstafeln für Rein- und Misch- 
bestände. Tagungsband der Sektion Ertragskunde des Deutschen Verbandes Forstlicher Forschungsanstalten, Treis-Karden/Mosel, 36-59.

Windhager, M. (1999): Evaluierung von vier verschiedenen Waldwachstumssimulatoren. PhD thesis, Universität für Bodenkultur Wien.

Wykoff, W.R. (1990): A basal area increment model for individual conifers in the Northern Rocky Mountains. Forest Science 36, 1077-1104.
Zingg, A. (1994): Top heights in mixed stands. Their definition and calculation. In: Pinto da Costa, M.E. and T. Preuhsler (Eds.): Mixed stands. Research plots, measurements and results, models. Proceedings from the symposium of the IUFRO Working Groups S.4.01-03: Design, Performance and Evaluation of Experiments. S.4.01-04 Growth models for Tree and Stand Simulation. Instituto superior de agronomia. Universidade técnica de Lisboa, Lousa/Coimbra, Portugal, 67-97. 